\title{
Socio Economic Factors Affecting Female Students Academic Performance at Higher Education
}

\author{
Wudie Atinaf and Philpose Petros*
}

Ethiopian Universities Partnership, Addis Ababa, Ethiopia

\begin{abstract}
In Ethiopia, female students' participation at all levels of education is increasing at an alarming rate. On the other hand the numbers of female students who graduate from higher learning institutions are less as compared with their male counter parts due to different factors which influences on their academic performance. This study was conducted with the objective of assessing socio-economic factors affecting the academic performance of female students in Bahir Dar University. The study adopted both qualitative and quantitative research approaches in which descriptive research method were employed by using non probabilistic and probabilistic sampling techniques. Questionnaire, Interview, observation, and relevant documents used to gather information applicable to the study. Analysis of the data was made by descriptive statistic by using frequency percentage and mean. The study focused on identifying and analyzing the socio economic (SE) factors affecting female students' academic performance in the university. The result of this study indicated that socio-economic factors such as economic status of parents, the expansion of khat (stimulating green leaf) shops, tourist centers and night clubs around the university affect female students' academic performance. Therefore, the government, ministry of education and the university should give attentions to promote female students academic achievement. The university should start working with regional government, city administration and community to promote female students academic achievement.
\end{abstract}

Keywords: Socio-economic factors; Female students; Academic performance; Higher education

\section{Introduction}

Education is the harmonious development of the physical, mental, moral (spiritual), and social faculties of individuals, for a life of dedicated service [1]. It is a tool that enables citizens to make all rounded participation in the development process. The participation of females in socio economic development programs also depends on their educational backgrounds. Educating girls and women is critical not merely to achieve personal benefits but also for the improvement in the areas of human resource development of the society [2].

The natural environment does not distinguish males and females. However, whenever the exposure of human beings to the natural environment occurred, both sexes started to differ in the nature and depth of their experiences. Later, the gender disparity that began in a small way, get widened by political, economic, cultural and other factors.

Education is one of the social factors where by gender disparity is reflected. In the field of education, the number of educated females is very low. As the grade level in school increases the number of female students starts to decline because of lots of factors [3]. Consequently, higher education remains an area of learning from which women are less represented. The very few women that are fortunate enough to join higher institutions are characterized by lower academic performance and higher forced withdrawal. As a result, such inequity in higher education representation has a serious lifelong impact on their opportunities to participate in the country's political power sharing, economic privileges as well as social representations. This is because, currently, joining higher education has become a path to upward social mobility status, political power, economic privilege and social prestige [1].

Female students' academic performance is lower as compared with male students at higher education. However, their participation is increasing time to time due to several factors affecting their academic performance. The purpose of this study was used to assess socioeconomic factors affecting female students academic performance at higher education particularly Bahir Dar University. In addition, the study points out possible valuable recommendation that would contribute to promote female students academic performance.

\section{Methodology}

A descriptive research design was applied in this study so as to clearly describe factors that affect female students' academic performance. Qualitative approach was used for the purpose of using non-numeric explanation to describe and compare the respondents' opinions or reviews for the open ended questionnaire with relative to the research topic and personal interview. Quantitative approach was also used for the purpose of using numeric explanation to describe respondents' response (female and male students' response on the questionnaires). Simple random sampling was employed to select samples from faculties and departments. In addition, purposive (non-probability) sampling was adopted to select samples from students at a class, staff members, management bodies, student councils, proctors, student dean, and gender office and dropout female students for interview purpose. One hundred fifty students completed the questioner and 13 (management bodies, students dean and council, gender office, proctor and dropout female students) were included in the interview. The quantitative data were analyzed using SPSS and qualitative data were analyzed by narration and summarization.

*Corresponding author: Philipos Petros, Ethiopian Universities Partnership POBOX 14051, Addis Ababa, Ethiopia, E-mail: multidisciplinary3@gmail.com

Received October 09, 2015; Accepted March 25, 2016; Published March 31 , 2016

Citation: Atinaf W, Petros P (2016) Socio Economic Factors Affecting Female Students Academic Performance at Higher Education. Health Care: Current Reviews 4: 163. doi: 10.4172/2375-4273.1000163

Copyright: ( 2016 Atinaf W, et al. This is an open-access article distributed under the terms of the Creative Commons Attribution License, which permits unrestricted use, distribution, and reproduction in any medium, provided the original author and source are credited. 


\section{Results}

\section{Socio-demographic data}

From 164 questionnaires distributed, 150 were completed. The completed questionnaires were from 120 female and 30 male students.

Analysis of data showed that there are different socioeconomic factors affecting the academic performance of female students at higher education. These are economic status of parents, the expansion of khat shops, tourist centers and night clubs around the university.

As respondents' response socio economic factors such as, economic status of parents, female students living outside University and being non café, limited employment opportunities and the presence and influx of tourists, expanding khat (Catha edulis) which is stimulating green leaf abundantly existing in the environs of universities. It also be sold in shops around the university gates and nearby, and night clubs/ bars, widespread hotel beds around the university affect female students academic performance at higher education level (Table 1).

In this study, the major problems of female students at higher education level are identified and analyzed. Among the problems faced by female students was found to be economic constraint. Economic constraints seriously affect female students' academic performance, which spans from the very limitation of purchasing the necessary educational materials to those affecting their health. Students from poor families failed to fulfill necessities such as education materials, cosmetics, recreation, etc. As a result, to get away from such trap they may be engaged in different immoral, and risky engagements such as sexual affairs and expose themselves to irreversible problems including HIV/AIDS and unwanted pregnancy and consequently they dropped out of the university and have extended consequences in their future life. The report from interviewed teachers confirmed that some students (mostly of rural origin) are exposed to such risky situations.

On the contrary, females' who are from poor economic background parents have low self-esteem as well as feel inferiority. Most of University students are in the age group of 21 to 25 years which implies that they are young, they want to know everything even that is not good for them, free from family control and enjoy with different group of people and new to the university environment. As a result, they want to try new things like chewing khat, going to night club and get entertained in the tourist places. Moreover, some unethical and immoral men who have better economic income such as older men in Amharic "Shuger Dady" for transactional and trans generational sexual malpractices outside the university is becoming the major negative factor that impacts the performance of female and young students. This is also a major factor for wasting or killing female students' reading and study time and using them as temporary sex mate.

Sadly, University gates are becoming destinations of such stupid activities. On the other hand, students who are economically better but were under close family control before joining the university, want to enjoy with different bodies by going to various unnecessary places which are mentioned above and also consider doing this kind of activities as a symbol for modernization. Girls' expectations of their school performance and career prospects play significant roles in their persistence at school. Female students' self-perception on their academic performance is lower and they perceive themselves they are academically weak and they believe that "we can't". Due to this they cannot use their effort as well as develop dependency on others .As demonstrated from the table above, the majority of respondents, which accounts $92.7 \%$, agreed on the effect of female students self-perception on their academic performance. Educated parents would perceive the need of females' education in a better way than those who are not educated.

Educated parents might also facilitate the girls' learning at home, encourage, continuous follow up and motivate them to score better academically. The analysis of data here in this study further confirmed this as seen in the table above. The lion share of respondents $(87.3 \%$ were agree) indicated that the level of parental education highly affect the academic performance of female students. Ager suggested that females' education is more strongly and adversely affected by parents who are illiterates than literates.

\section{Conclusions and Recommendations}

The purpose of this study was to asses factors affecting the academic performance of female students at higher education and to suggest possible solutions that may help to promote female students academic performance.

\begin{tabular}{|c|c|c|c|c|c|c|}
\hline \multicolumn{7}{|c|}{ Factors affecting female students at higher education } \\
\hline \multirow[b]{2}{*}{ Factors } & \multirow[b]{2}{*}{ Respondents } & \multicolumn{5}{|c|}{ Rating scale } \\
\hline & & $\begin{array}{l}\text { Strongly } \\
\text { agree }\end{array}$ & Agree & Neutral & Disagree & $\begin{array}{l}\text { Strongly } \\
\text { Disagree }\end{array}$ \\
\hline \multirow{2}{*}{ Limited employment opportunities affect female academic performance } & Frequency & 58 & 78 & 4 & 8 & 2 \\
\hline & Percentage & 38.7 & 52.0 & 2.7 & 5.3 & 1.3 \\
\hline \multirow{2}{*}{ Economic status of parents affect female academic performance } & Frequency & 65 & 70 & 5 & 7 & 3 \\
\hline & Percentage & 43.3 & 46.7 & 3.3 & 4.7 & 2.0 \\
\hline \multirow[b]{2}{*}{ Female students living outside the university } & Frequency & 55 & 77 & 5 & 8 & 3 \\
\hline & Percentage & 36.7 & 51.3 & 3.3 & 5.3 & 2.0 \\
\hline \multirow{2}{*}{ Female students becomes non café } & Frequency & 37 & 91 & 7 & 12 & 2 \\
\hline & Percentage & $24.7 \mathrm{~s}$ & 60.7 & 4.7 & 8.0 & 2.0 \\
\hline \multirow[t]{2}{*}{ Presence of tourist centers around the university affects academic performance of females } & Frequency & 42 & 94 & 5 & 8 & 0 \\
\hline & Percentage & 28.0 & 62.7 & 3.3 & 5.3 & 0.0 \\
\hline \multirow[t]{2}{*}{ Presence of chat shops around the university negatively affect females academic performance } & Frequency & 57 & 70 & 6 & 8 & 8 \\
\hline & Percentage & 38.0 & 46.7 & 4.0 & 5.3 & 5.3 \\
\hline \multirow{2}{*}{ Presence of night clubs/ bars/ around the university affects academic performance of females } & Frequency & 87 & 51 & 3 & 5 & 3 \\
\hline & Percentage & 58.0 & 34.0 & 2.0 & 3.3 & 2.0 \\
\hline
\end{tabular}

Table 1: Diferent socio-economical factors that affect female academic performance. 
Citation: Atinaf W, Petros P (2016) Socio Economic Factors Affecting Female Students Academic Performance at Higher Education. Health Care: Current Reviews 4: 163. doi: 10.4172/2375-4273.1000163

Page 3 of 3

The research has tried to identify and analyze socio economic factors that affect female student's academic performance. Such factors are, the presence of night clubs/bar, khat shops, and tourist centers around the university, economic status of parents, limited employment opportunities, and female students living outside the university and becoming non café are affecting female students' academic performance.

The attrition rate of Bahir Dar University female students was high in a decreasing rate in the last five years due to different cause of failure. Such as, sexual harassment, there were no supportive trainings provided by the university, fear of failure, female students self-perception on their academic performance, lack of self-confidence, and community attitude towards female students performance. Even if the trend of female students' attrition rate in BDU is decreasing from time to time, still female students attrition rate is present in the university and needs to do more in this area.

Based on results and conclusions drawn, the following suggestions are proposed to promote female students academic performance:

- The university should control (by effectively executing its workplace policies and collaborative work practices) the opening of khat shops and night/bar/ clubs around the university by collaborating with regional government.
- The university should give recognition and rewards for well performer female students to motivate other female students.

- The university should create means of paying special attention to students from low socio-economic backgrounds, students with disabilities (HIV/AIDS) and joined the university from rural areas.

- The government should give financial/economical support for economically disadvantaged female students through evidence based income generating schemes and working in collaboration with relevant partners including the Ethiopian Higher Education partnership forum, donors and media.

\section{References}

1. Eshetu A (2002) Factors Affecting Participation of Females in Secondary in Gambella Region. A Thesis Presented to the School of Graduate Studies of Addis Ababa University.

2. Egenti M, Omoruyi F (2011) Challenges of Women Participation in Continuing Higher Education Programme: Implications for Adult Women Counseling and Education. Edo Journal of Counseling 4: 1-2.

3. Mersha Y, Alemayehu B, Asrat A, Nigussie A (2009) The study of policy intervention on factors affecting female students' academic achievement and causes of attrition in higher learning institutions of Ethiopia. 